\title{
善 EKOLOŠKI ASPEKTI NACIONALNOG SISTEMA BEZBEDNOSTI SAGLEDANI KROZ PRIZMU DELOVANJA ORGANIZACIJE UN U KRIZNIM PODRUČJIMA - STUDIJA SLUČAJA: HAITI (2004-2017)
}

\author{
(Kritički osvrt na nesrazmernost napora uloženih u razvoj sistema \\ nacionalne i ekološke bezbednosti) \\ Slavimir S. Nikolić \\ Univerzitet EDUCONS, Fakultet za primenjenu bezbednost, \\ Sremska Kamenica - Novi Sad
}

\begin{abstract}
Oosmatrajući Haiti sa aspekta ekološke bezbednosti jasno je da najveći problem po pitanju nacionalne bezbednosti ove karipske države nije isključivo njen fizički aspekat ili stabilnost političkog sistema. Uporedna analiza ulaganja u razvoj sistema nacionalne i ekološke bezbednosti na Haitiju u periodu od 2004. do 2017. godine ukazuje na ekstremne nesrazmernosti i umanjenje ulaganja međunarodnih činilaca i same države u sistem nacionalne bezbednosti, pri čemu se minimalno ulaže u sistem ekološke bezbednosti. Degradacija već uništenog eko-sistema i životne sredine Haitija predstavlja ozbiljnu pretnju opstanku celokupne nacije, pri čemu država ne poseduje defanzivne kapacitete da se bilo oporavi od šokova kojima je izložena usled negativnog delovanja uzastopnih elementarnih ili manmade nepogoda. Sa najavljenim povlačenjem mirovne operacije UN MINUSTAH sa Haitija izvesna degradacija eko-sistema i životne sredine verovatno će dovesti do backfire efekta na do sada ostvarene relativne uspehe organizacije UN u stabilizaciji bezbednosnog okruženja. Odlaganje kvalitativnog pomaka u promeni evidentno negativnog trenda po pitanju ekološke bezbednosti Haitija predstavlja tempiranu bombu u formatu neizbežne ekološke katastrofe, čije će nerešavanje, po svemu sudeći, doprineti evoluciji novih nestabilnosti i urušavanja sistema šire nacionalne bezbednosti u skoro nastupajućem post-UN periodu. Dakle, degradacija eko-sistema Haitija predstavlja validnu latentnu negaciju uspeha organizacije UN u stabilizaciji nacionalnog bezbednosnog okruženja države primaoca pomoći.
\end{abstract}

Ključne reči: UN, MINUSTAH, međunarodna zajednica, Haiti, bezbednosno okruženje, ekološka bezbednost, životna sredina, eko-sistem, ulaganja

\footnotetext{
* Autor je dugogodišnji analitičar organizacije UN. Izneseni stavovi pripadaju autoru i ne odražavaju stavove organizacije UN; nikolics@un.org.
} 
Savet bezbednosti organizacije UN uspostavio je na Haitiju 2004. godine, u skladu

Sa preporukama generalnog sekretara UN, stabilizacionu mirovnu operaciju poznatu pod njenim akronimom MINUSTAH (United Nations Stabilization Mission in Haiti). ${ }^{1}$ Prvobitno autorizovana na inicijalni period od šest meseci, međunarodna organizacija angažovala je svoje snage i sredstva usled postojanja značajnih izazova za političku, socijalnu i ekonomsku stabilnosti Haitija, te mogućim spill-over regionalnim destabilizacionim efektom, a u okviru mandata koji predviđa osiguranje stabilnog okruženja, restrukturiranje i reformu nacionalne policije, pomoć u razoružanju, demobilizaciji i reintegraciji oružanih grupa, pomoć u uspostavljanju vladavine prava, podršku političkih procesa, te organizaciju slobodnih izbora. ${ }^{2}$

Mandat MINUSTAH-a produžavan je narednih 14 godina, što je doprinelo stabilizaciji bezbednosnog okruženja Haitija, ${ }^{3}$ u skladu sa čim je, marta 2017. godine, odlučeno da se ova misija UN konačno ukine te uspostavi manja follow-up misija fokusirana na razvoj vladavine prava; a uz znatno umanjenje budžeta i mirovnih trupa. ${ }^{4}$

lako u delu međunarodne zajednice i političkim krugovima na Haitiju postoje mišljenja da je posao UN u ovoj državi daleko od završenog, da kapaciteti još uvek nerazvijene nacionalne policije nisu dorasli bezbednosnim izazovima i nivou političke stabilnosti, te da odluka Saveta bezbednosti može u bliskoj budućnosti doprineti nastanku bezbednosnog vakuuma ili čak eliminacije do sada postignutih uspeha u stabilizaciji Haitija, jedna činjenica je nepobitna - UN su radi unapređenja sistema nacionalne bezbednosti Haitija ulagale od 2004. (min.), preko 2011. godine (maks.), pa do danas od $478^{5}$ do $844^{6}$ miliona USD godišnje. Pojednostavljenja radi, a uzimanjem u obzir aritmetičke sredine tih budžeta, UN su putem postojećih MINUSTAH mehanizama uložile u stabilizaciju Haitija od 2004. godine oko 8,6 milijardi USD.

Posmatrajući Haiti sa aspekta stanja eko-sistema i životne sredine, nalazimo da najveći problem po pitanju nacionalne bezbednosti ove karipske nacije nije isključivo fizički aspekat ili stabilnost državotvornih institucija i političkog sistema. Usled geografskog položaja, specifičnog reljefa, te decenija zanemarivanja obeju prvobitno navedenih faktora,

\footnotetext{
${ }^{1}$ Security Council Establishes UN Stabilization Mission In Haiti For Initial Six-Month Period, http://www.un.org/press/en/2004/sc8083.doc.htm

${ }^{2}$ MINUSTAH Background, http://www.un.org/en/peacekeeping/missions/minustah/background.shtml

${ }^{3}$ Report of the Secretary-General on the United Nations Stabilization Mission in Haiti, http://www.undocs.org/S/2017/223

${ }^{4}$ Security Council Grants Final Mandate Extension for United Nations Stabilization Mission in Haiti, Unanimously Adopting Resolution 2350 (2017), https://www.un.org/press/en/2017/sc12794.doc.htm

${ }^{5}$ Budget for the United Nations Stabilization Mission in Haiti for the period from 1 July 2005 to 30 June 2006 and expenditure report for the period from 1 May to 30 June 2004,

http://www.un.org/ga/search/view_doc.asp?symbol=A/59/745

${ }^{6}$ Financing of the United Nations Stabilization Mission in Haiti, http://www.un.org/ga/search/view_doc.asp?symbol=A/RES/65/256B

${ }^{7}$ Detalji uvid u tačan iznos sume 13 budžeta UN za MINUSTAH dostupan putem baze podataka na: http://www.un.org/ga/acabq/documents/all?type $\% 5 B \% 5 \mathrm{D}=$ report\&type $\% 5 \mathrm{~B} \% 5 \mathrm{D}=$ document\&year $\% 5 \mathrm{Bvalue} \% 5$ D\%5B\%5D=2011\&keys=MINUSTAH
} 
Haiti se danas nalazi u samom vrhu zemalja koje su izrazito osetljive na negativno delovanje prirodnih sila i imaju visok disaster-prone faktor. Haiti je zvanično i najsiromašnija i ekološki najdegradiranija zemlja u zapadnoj hemisferi, sa izuzetno niskim Human Development indeksom (uključujući environmental sustainability), i nalazi se na 163. poziciji od ukupno 188 posmatranih država sveta. ${ }^{8}$

Nasuprot postojanju brojnih studija koje opisuju bezbednosne i socio-ekonomske izazove koji uslovljavaju stagnaciju ili relativno nazadovanje ove države, malo je onih koje govore o ozbiljnosti uništavanja prirodnog okruženja Haitija, bez obzira na „privilegovane" uslove u kojima se nalazi usled dugogodišnje pažnje koju uživa od međunarodne zajednice.

Pretpostavljajući da razumevanje važnosti eko-sistema i životne sredine u sveukupnosti nacionalne bezbednosti nisu bili dominantan predmet pažnje međunarodne zajednice, a sa aspekta mandata mirovne operacije MINUSTAH, to se ne može odnositi na rad nacionalnih autoriteta (Ministère de l'Environnement d'Haiti) ${ }^{9}$ Haitija, te specijalizovanih agencija organizacije UN, kao što je UNEP (UN Environment Programme), ${ }^{10}$ UNDP (UN Development Programme) ${ }^{11}$ ili bilateralnih agencija tipa USAID (US Agency for International Development) ${ }^{12}$ značajno orijentisanih, pored ostalog, na agende životne sredine (UNEP), održivog razvoja (UNDP), te razvoja unutrašnjih potencijala i sistemske otpornosti zemalja (USAID).

Nepoznanica koja se pri tome pojavljuje, u odnosu na postojeći precizan uvid u ulaganja međunarodne zajednice u stabilizaciju bezbednosnih prilika zemlje primaoca pomoći, jeste iznos koji je investiran u skorijoj istoriji prisustva organizacije UN na Haitiju u identifikaciju i delovanje radi ublažavanja dalje degradacije eko-sistema i životne sredine, a kao elemenata sa kapacitetom značajne pretnje sveukupnosti nacionalne bezbednosti. Upravo ta nepoznanica (void), kao i nedostatak komparativne kvantitativne analize koja bi opisala odnos ulaganja u domen fizičke i ekološke bezbednosti nacije, čija dugoročna stabilnost i bezbednost zavisi i od stanja već znatno narušenog eko-sistema i životne sredine, pokreće ovo naučno istraživanje.

Bez obzira na činjenicu da je pod lupom pažnje međunarodne zajednice, Haiti nema mogućnosti da spreči dalji kolaps svog eko-sistema i životne sredine. Ta činjenica u perspektivi predstavlja tempiranu bombu u formatu neizbežne ekološke katastrofe čije nerešavanje neizostavno mora doprineti evoluciji novih nestabilnosti i urušavanja sistema nacionalne bezbednosti u nastupajućem post-UN periodu. Shodno tome, radna hipoteza postavljena u ovom radu jeste da degradacija eko-sistema i životne sredine Haitija predstavlja latentnu negaciju uspeha međunarodne organizacije ostvarenih u periodu od 2004. do 2017. godine u procesu stabilizacije nacionalnog bezbednosnog okruženja.

U tom smislu, analitički pristup u izučavanju date problematike čine komparativne analiza: (1) ulaganja UN i nacionalnih institucija države u unapređenje bezbednosnog okruženja naspram onih uloženih u sprečavanje dalje degradacije eko-sistema i životne sredine Haitija i

\footnotetext{
${ }^{8}$ Haiti, Human Development Indicator, http://hdr.undp.org/en/countries/profiles/HTI .

${ }^{9}$ https://unfccc.int/resource/ccsites/haiti/

${ }^{10}$ http://web.unep.org/

${ }^{11} \mathrm{http}: / /$ www.undp.org/content/undp/en/home.html

${ }^{12}$ https://www.usaid.gov/
} 
(b) stanja eko-sistema i životne sredine Haitija pre uspostavljanja mirovne operacije MINUSTAH, u toku njenog funkcionisanja i izraženog prisustva međunarodne zajednice na Haitiju (od 2004. do 2017. godine), te u periodu neposredno pred ukidanje ove mirovne operacije.

Izvori koji se koriste u ovom istraživanju pripadaju isključivo grupi javno dostupnih: iz domena rada UN, mirovne operacije UN MINUSTAH, specijalizovanih agencija UN ili individualnih država, institucija države Haiti, te izvori koji se odnose na predmetna istraživanja koja su preduzele vladine i-ili nevladine, te transnacionalne neprofitne organizacije i društva, think-tank grupe, nezavisna akademska istraživanja, te kredibilne medijske organizacije.

Ovaj rad ne predstavlja kritiku funkcionisanja UN, već mu je cilj sticanje uvida u problematiku ekoloških aspekata nacionalnog sistema bezbednosti, sagledanih kroz prizmu delovanja međunarodne organizacije u kriznim područjima, pa može poslužiti kao praktičan primer direktnog uzročno-posledičnog odnosa ova dva bezbednosna elementa.

\section{ANALIZA: Ulaganja organizacije UN i Haitija u unapređenje bezbednosnog okruženja}

Uvid u ukupan iznos nacionalnog ulaganja i ulaganja UN u unapređenje bezbednosnog okruženja Haitija izvršen je uzrokovanjem poslednje tri finansijske godine $(F Y){ }^{13}$ odnosno tri poslednja budžeta mirovne operacije MINUSTAH koje su odobrili Savet bezbednosti UN i budžet Haitija za 2014/2015, 2015/2016. i 2016/2017. (FY) godinu.

Kako pokazuju javno dostupni zvanični podaci, UN su u poslednje tri finansijske godine uložile u funkcionisanje MINUSTAH-a, kao stabilizacionog elementa bezbednosnog okruženja Haitija, ukupno 1 milijardu i 284.2 miliona USD, tj. 539,1 miliona USD $(2014 / 2015),{ }^{14} 399,2$ miliona USD $(2015 / 2016)^{15}$ i 345.9 miliona USD $(2016 / 2017){ }^{16}$

Sa druge strane, kako navodi Ministarstvo finansija Haitija (Le Ministère de l'Economie et des Finances), ${ }^{17}$ tj. podaci publikovani u zvaničnom nacionalnom glasniku (Le Moniteur), ${ }^{18}$ ulaganja države Haiti u održavanje i unapređenje fizičkog aspekta bezbednosnog okruženja iznosilo je u poslednjem trogodišnjem periodu, putem budžeta alociranih nacionalnoj policiji (Police Nationale $d^{\prime}$ Haiti) $^{19}$ i Ministarstvu odbrane ${ }^{20}$ (Ministere de la

\footnotetext{
${ }^{13}$ Fiscal Year

${ }^{14}$ Financing of the United Nations Stabilization Mission in Haiti, http://www.un.org/ga/search/view_doc.asp?symbol=A/RES/68/289

${ }^{15}$ Financing of the United Nations Stabilization Mission in Haiti, http://www.un.org/ga/search/view_doc.asp?symbol=A/RES/69/299

${ }^{16}$ Report of the Secretary-General on the United Nations Stabilization Mission in Haiti, https://minustah.unmissions.org/sites/default/files/s2016753_en.pdf

${ }^{17}$ http://www.mef.gouv.ht/

${ }^{18}$ Le Moniteur, journal officiel de la république d'Haïti

${ }^{19}$ http://www.pnh.ht/

${ }^{20}$ Vojska Haitija je raspuštena predsedničkim dekretom (Jean Bertrand Aristide) 1994. godine kao liabilitet po opštu bezbednost, a ponovo uspostavljena predsedničkim dekretom (Evans Paul) iz 2015. godine. Haitian Government Reinstates the Army, http://www.globalresearch.ca/haitian-government-reinstates-the-army/5494680
} 


\section{Ulaganja međunarodne zajednice i Haitija u unapređenje eko-sistema i životne sredine}

Na osnovu uvida u budžet UNEP-a dolazimo do informacije ${ }^{26}$ da godišnji globalni ${ }^{27}$ budžet ovog dela sistema UN, ${ }^{28}$ aktivno prisutnog u oko 100 država sveta i sa mandatom koordinacije ekoloških aktivnosti, te pomoći zemljama u razvoju u realizaciji ekoloških programa, za 2016. godinu iznosi oko 463 miliona USD. ${ }^{29}$ Imajući u vidu ovaj relativno nizak iznos u odnosu na globalno prisustvo ove organizacije, te činjenicu da je prisustvo UNEP-a na Haitiju ograničeno na jedan jedini projekat, ${ }^{30}$ koji se realizuje od 2008 . godine i to u samo jednoj od 145 postojećih komuna ${ }^{31}$ ove države, usmerenog na postizanje održivog razvoja (čak i ne dotičući ozbiljnije probleme eko-sistema i životne sredine), realna procena $^{32}$ je da godišnji budžet UNEP-a na Haitiju ne iznosi više od 2 do 3 miliona USD. Ne raspolažući preciznijim otvoreno dostupnim informacijama o budžetu UNEP-a na Haitiju u periodu od 2015. do 2017. godine, može se reći da je ta pretpostavka validna, te se taj iznos može uzeti kao srednja godišnja vrednost. Kao dodatna teorijska podrška takvoj percepciji služi informacija da je pomenuti projekat dugogodišnjeg i zaista skromnog karaktera, te da o njemu postoji samo štura truncated informacija dostupna na internetu, indikujući da ovaj budžet u 2015. godini iznosi 2,4 miliona USD. ${ }^{33}$ Dakle, pretpostavka o prosečnom godišnjem ulaganju UNEP-a na Haitiju u navedenom periodu može se smatrati validnom.

\footnotetext{
${ }^{21} \mathrm{http}: / /$ www.md.gouv.ht/

${ }^{22}$ Nacionalna valuta Haitija "gourd" (HTG) znatno je devalvirala u periodu 2014-2017. Korekcije kursa u proračunu uzete su u obzir. Petogodišnja kursna lista sa prikazom USD i HTG dostupna na: http://www.xe.com/currencycharts/?from=USD\&to=HTG\&view=5Y

${ }^{23}$ Budget général de la République 2014-2015, str. 30, http://www.mef.gouv.ht/upload/doc/Budget_Rectificatif_14-15.pdf

${ }^{24}$ Budget général de la République 2015-2016,str. 25, http://dgi.gouv.ht/wp-content/uploads/2016/03/Budget_initial_2015-2016.pdf

${ }^{25}$ Budget général de la République 2016-2017, str. 24, http://www.mef.gouv.ht/upload/doc/Budget-2016-2017.pdf

${ }^{26} \mathrm{U}$ skladu sa dostupnim informacijama putem otvorenih izvora.

${ }^{27}$ UN Environment Project Presence (30 Juna 2016. godine), http://uneplive.unep.org/redesign/theme/index/11\#maps

${ }^{28}$ The UN System: http://cifal-flanders.org/united-nations/un-system/

${ }^{29}$ UN Regular Budget and Environment Fund, http://www.unep.org/about/funding/our-funding/overview

30 The Haiti 'Grand Sud' Programme, http://drustage.unep.org/disastersandconflicts/where-wework/hait//what-we-do/haiti-\%E2\%80\%98grand-sud\%E2\%80\%99-programme

${ }^{31}$ Haïti - Politique: 5 nouvelles communes en Haïti, http://www.haitilibre.com/article-14858-haiti-politique-5nouvelles-communes-en-haiti.html

${ }^{32}$ Procena u odnosu na dostupne informacije UNEP na http://uneplive.unep.org/redesign/theme/index/11\#maps

${ }^{33}$ Google search: „UNEP grand sud project finances“, „This project (USD 2.417 million budget), implemented by UNEP..."
} 
Za razliku od nedovoljne internet (open sources) budžetske transparentnosti aktivnosti UNEP-a na Haitiju, situacija sa UNDP je mnogo jasnija. Zvanični podaci ove razvojne programske inicijative organizacije UN, globalno prisutne i aktivne u oko 170 zemalja i teritorija čiji je cilj iskorenjivanje siromaštva i zaštite životne sredine, ${ }^{34}$ ukazuju na značajnije prisustvo i aktivnosti na Haitiju u posmatranim domenima, a pored ostalih aktivnosti koje preduzima. ${ }^{35}$ Tačnije, UNDP ima trenutno pet aktivnih programskih aktivnosti na Haitiju, ${ }^{36}$ iniciranih u periodu od 2011. godine, a sa ukupnim budžetom od ukupno 19,8 miliona USD, raspoređenog na sledeći način: (1) Développement de l'hydroélectricité sur petite échelle en Haïti sa 1,2 miliona USD, ${ }^{37}$ (2) Renforcement des capacités adaptatives des communautés côtières d'Haïti aux changement climatique sa 6,5 miliona USD, ${ }^{38}$ (3) Programme de Micro Financement sa 1,4 miliona USD, ${ }^{39}$ (4) Appui au Renforcement des Capacités du Ministère de l'Environnement sa 1,2 miliona USD, i (5) Adaptation basée sur les écosystèmes sa 9,5 miliona USD. ${ }^{40}$ Odnosno, realna je procena da je UNDP ulagao u podršku i razvoj eko-sistema i životne sredine Haitija oko 2,8 miliona USD godišnje (od 2011. do 2017. godine).

Veoma precizne informacije dostupne upotrebom open source pretraživačkih mehanizama nepobitno ukazuju na činjenicu da USAID, američka agencija za međunarodni razvoj, odgovorna za administraciju civilne pomoći drugim zemljama, u kontinuitetu predstavlja najznačajnijeg kontributora međunarodne zajednice u podršci eko-sistema i životne sredine na Haitiju, a između brojnih aktivnosti i programa koje ta agencija izvodi u ovoj državi i globalno. ${ }^{41}$ Raspoloživi podaci ukazuju na to da je USAID na Haitiju u periodu od 2011. do 2015. godine preduzela 25 aktivnosti - projekata u domenu zaštite životne sredine, ${ }^{42}$ sa ukupnim budžetom od 40,7 miliona USD, ${ }^{43}$ odnosno oko 8,1 miliona USD godišnje. lako navedena uložena sredstava mogu biti posmatrana kao relativno mala, sa stanovišta njihove uporedbe sa onima koje oslikavaju aktivnosti UNEP ili UNDP, USAID svakako dominira.

Konačno, osvrćući se na učešće i ulogu samih institucija države Haiti u unapređenje vlastitog eko-sistema i životne sredine, već ranije navedeni open source dostupni podaci ukazuju na to da godišnji nacionalni budžeti usmereni ka ovom portoliju društvenog živo-

\footnotetext{
${ }^{34}$ http://www.undp.org/content/undp/en/home/operations/about_us.html

${ }^{35}$ Projekti UNDP na Haitiju detaljno na:

http://www.ht.undp.org/content/hait//fr/home/operations/projects/overview.html

${ }^{36}$ Detaljan uvid u opis projekata usmerenih na podršku i razvoj Eko-sistema i zaštitu životne sredine dostupan na: http://www.ht.undp.org/content/haiti/fr/home/operations/projects/environment_and_energy.html

${ }^{37} \mathrm{http}: / / \mathrm{ww} w$.ht.undp.org/content/hait//fr/home/operations/projects/environment_and_energy/projet-hydroelectricite.html

${ }^{38} \mathrm{http} / / /$ www.ht.undp.org/content/haiti/fr/home/operations/projects/environment_and_energy/renforcementdes-capacites-adaptatives-des-communautes-cotieres-.html

39 http://www.ht.undp.org/content/hait//fr/home/operations/projects/environment_and_energy/programme-demicro-financement.html

${ }^{40}$ http://www.ht.undp.org/content/haiti/fr/home/operations/projects/environment_and_energy/adaptationbasee-sur-les-ecosystemes.html

41 Detaljan opis i zastupljenost aktivnosti USAID dostupno na: https://www.usaid.gov/what-we-do i https://www.usaid.gov/where-we-work

${ }^{42}$ Download data, Haiti: https://results.usaid.gov/data

${ }^{43}$ Dollars to Results, Environment in Haiti, https://results.usaid.gov/haiti/environment\#fy2015
} 
ta, a izraženi u sredstvima alociranim Ministarstvu za zaštitu životne sredine (Ministere de ( Environnement), ${ }^{44}$ u poslednjem trogodišnjem periodu iznose oko 17,6 miliona USD, tj. 5,1 miliona USD $(2014 / 2015),{ }^{45} 6,7$ miliona USD $(2015 / 2016)^{46}$ i 5,8 miliona USD $(2016 / 2017){ }^{47}$

\section{Stanje eko-sistema i životne sredine Haitija u pre-MINUSTAH periodu}

Ozbiljni nedostaci i bezbednosne implikacije vezane za stanje eko-sistema i životne sredine Haitija nisu novog datuma, odnosno prethode uspostavi misije MINUSTAH i robustnijeg angažovanja međunarodne organizacije na teritoriji ove države.

Jedan od značajnijih, vremenski relevantnih akademskih pristupa ovom problemu, u potpunosti usmeren problematici razmatranoj u ovom istraživanju, datira još iz 1998. godine (Canadian International Development Agency, Environmental Scarcities And Conflict in Haiti) ${ }^{48}$ koji opisuje Haiti kao najsiromašniju i ekološki najdegradiraniju državu u zapadnoj hemisferi. Studija definiše Haiti kao lokaciju sa izuzeto osetljivom ekologijom, nepovoljnim klimatskim uslovima (sezone suša sa jedne strane i sezone snažnih ciklona i uragana sa druge) koji negativno utiču na eko-sistem, višedecenijskom deforestacijom (drveni ugalj principijelni energent), erozijom tla i nedostatkom vodnih izvora. Takvi uslovi su neumitno uzrokovali značajne nestašice resursa životne sredine i prisiljavali stanovništvo iz ruralnih sredina na masovnu migraciju u još više ekološki osetljiva i neuređena gradska okruženja (slums).

\section{Stanje eko-sistema i životne sredine Haitija u MINUSTAH periodu (2004-2017)}

Potvrda o zabrinjavajućem stanju eko-sistema i životne sredine Haitija može se naći i u nezavisnoj studiji iz 2009. godine (International Crisis Group, Haiti: Saving the Environment, Preventing Instability and Conflict), ${ }^{49}$ koja takođe sagledava međusobni odnos ži-

\footnotetext{
${ }^{44}$ https://unfccc.int/resource/ccsites/haiti/

${ }^{45}$ Budget général de la République 2014-2015, str. 17, http://www.mef.gouv.ht/upload/doc/Budget\%202014$2015 \% 2030 \% 20$ pages.pdf

${ }^{46}$ Budget général de la République 2015-2016, str. 15, http://dgi.gouv.ht/wp-content/uploads/2016/03/Budget_initial_2015-2016.pdf

${ }^{47}$ Budget général de la République 2016-2017, str. 16. http://www.mef.gouv.ht/upload/doc/Budget-2016-2017.pdf

${ }^{48}$ Environmental Scarcities And Conflict in Haiti, Ecology and Grievances in Haiti's Troubled Past and Uncertain Future, Philip Howard, For the Canadian International Development Agency, June 1998, Contract No. 26248, http://www.gvsu.edu/cms3/assets/53940C9B-B252-5B69-

626B48622A4C1002/publishedliterature/haitienvironmental_scaricity.pdf

${ }^{49}$ Haiti: Saving the Environment, Preventing Instability and Conflict, Policy Briefing, International Crisis Group, Latin America and Caribbean Briefing $\mathrm{N}^{\circ} 20$, Port-au-Prince/Brussels, 28 April 2009, https://www.crisisgroup.org/latinamerica-caribbean/haiti/haiti-saving-environment-preventing-instability-and-conflict
} 
votne sredine i bezbednosnog okruženja, a problem degradiranja životne sredine u ovoj državi definiše kao višedecenijski, duboko ukorenjen, dodatno znatno otežan socijalnim, ekonomskim i političkim previranjima. U studiji se posebno ističe izuzetna osetljivost Haitija na negativno delovanje prirode (environmental volatility), navodeći kao primer uzastopne katastrofalne poplave u periodu maj-septembar 2004. godine, te brojne druge iz perioda 2008. i 2009. godine usled izuzetnih kišnih sezona i aktivnih uragana. ${ }^{50}$ One su prouzrokovale smrt više od 3.000 lica i kolektivno stradanje desetina hiljada porodica, dodatno upozoravajući da je ekološka katastrofa na Haitiju „tempirana bomba” koju je neophodno demontirati kako bi se sprečila dalja destabilizacija i kontinuirano nazadovanje ove države. ${ }^{51}$

U januaru 2010. godine Haiti je pogodio razorni zemljotres (7,0 rihtera) koji je u toku od samo nekoliko minuta usmrtio 222.570 lica, na desetine hiljada lica je bilo povređeno ili je pretrpelo trajne posledice, oko 1,5 milion lica je ostalo bez krova nad glavom i preko 300.000 infrastrukturnih objekata je potpuno uništeno. ${ }^{52}$ Kao da već nemajući nesagledive nerešene probleme po pitanju eko-sistema i životne sredine, ${ }^{53}$ masivni zemljotres ostavlja za sobom mnoštvo dodatnih, ${ }^{54}$ pri čemu njihovo rešavanje iziskuje značajna i dugotrajna dodatna ulaganja međunarodne zajednice. Ona su u periodu naredne dve godine iznosila oko 6,4 milijarde USD, ${ }^{55}$ a sa projekcijom neophodnih sredstava do 2020. godine $u$ iznosu od 13,3 milijarde USD. ${ }^{56}$ Naravno, imajući u vidu srazmere ove prirodne katastrofe, većina od ovih sredstava bila je namenjena recovery procesu, indirektno stabilizaciji opšte bezbednosne situacije, tj. humanitarnim svrhama. Dakle, opet neće biti ulagano u eko-sistem i životnu sredinu.

Štaviše, već u oktobru 2010. godine na Haitiju izbija epidemija zarazne bolesti kolere, usled „eksterno indukovanog virusa”, ${ }^{77}$ i nepovoljne kombinacije klimatskih uslova, te degradiranosti i osetljivosti eko-sistema i životne sredine. Do 2017. godine ova bolest ubija preko 9.500 lica i od nje oboleva preko 806.000 lica. ${ }^{58}$ Ujedinjene nacije predviđaju da se radi ublažavanja ove epidemije angažuje, u periodu od 2016. do 2022. godine, sa pro-

\footnotetext{
${ }^{50}$ Klimatski kalendar i kalendar dešavanja: http://www.fews.net/file/87819, https://en.wikipedia.org/wiki/2004_Atlantic_hurricane_season

${ }^{51}$ lbidem futnoti \#50.

${ }^{52}$ Report of the Secretary-General on the United Nations Stabilization Mission in Haiti, 22 February 2010, http://www.securitycouncilreport.org/atf/cf/\%7B65BFCF9B-6D27-4E9C-8CD3-

CF6E4FF96FF9\%7D/Haiti\%20S2010\%20200.pdf

${ }^{53}$ Dalje uništavanje šuma Haitija, nestajanje biodiverziteta i nepostojanje zaštićenih područja, dalja erozija zemljišta, zagađenje izvora pijaće vode, uništavanje morskog i obalskog života.

${ }^{54}$ Monitoring novih geofizičkih i hidrometeoroloških promena, nesagledivi iznos otpadnog materijala i opasnih materija, kapacitet vektorskog širenja virusa kolere, menadžment ruševina itd.

${ }^{55}$ Office of the UN SG Special Adviser, Aid to Haiti after the January 12, 2010 earthquake, http://www.lessonsfromhaiti.org/lessons-from-haiti/key-statistics/

${ }^{56}$ Ibidem.

${ }^{57}$ Final Report of the Independent Panel of Experts on the Cholera Outbreak in Haiti, http://www.un.org/News/dh/infocus/haiti/UN-cholera-report-final.pdf , UN's Ban apologizes to people of Haiti, outlines new plan to fight cholera epidemic and help communities,

http://www.un.org/apps/news/story.asp?NewsID=55694\#.WQfmDRMrldU

${ }^{5} \mathrm{PAHO}-\mathrm{WHO}$, Epidemiological Update, Cholera in the Americas - Situation summary, http://reliefweb.int/sites/reliefweb.int/files/resources/2017-feb-23-phe-epi-update-cholera.pdf
} 
sečnim godišnjim iznosom od 8 do 10 miliona USD, ${ }^{59}$ dok 2016. godine uspeva da mobiliše 59 miliona USD za realizaciju bezmalo 300 relevantnih projekata i podržavajući vladu Haitija u mobilizaciji oko 307 miliona USD za potrebe realizacije Nacionalnog plana za koleru. ${ }^{60}$ Identično slučaju reakcije UN na zemljotres iz 2010. godine, i ovom prilikom uložena sredstava ubrizgavaju se u realizaciju relief procesa, indirektno stabilizaciju opšte bezbednosne situacije, tj. humanitarnim svrhama. Kao i u prethodnom slučaju, nema ulaganja u eko-sistem i životnu sredinu.

Da Haiti zaista jeste država koja je izuzetno podložna negativnom delovanju prirodnih sila dokazuje i poslednji značajan događaj iz oktobra 2016. godine, kada uragan Matthew $^{61}$ pogađa južni krak teritorije (oko $40 \%$ površine Haitija), prouzrokuje ogromna razaranja flore i faune, uništava do $80 \%$ poljoprivrednog sistema, prouzrokuje više od stotinu žrtava, znatno pogađa više od 350.000 lica $^{62}$ i inicira humanitarnu asistenciju (relief) za preko 1,4 miliona lica. ${ }^{63}$ Vrednost hitne realizacije procenjivao se na 139 miliona USD, ${ }^{64}$ bez ulaganja u eko-sistem i životnu sredinu.

\section{Stanje eko-sistema i životne sredine Haitija u periodu očekivanog ukidanja MINUSTAH-a}

Razmatrajući informacije evidentno najaktivnijeg entiteta međunarodne zajednice u domenu pružanja konkretne pomoći Haitiju u pogledu očuvanja eko-sistema i unapređenja životne sredine, agencije USAID, poslednji izveštaj ove organizacije u domenu ovde razmatrane oblasti ${ }^{65}$ već u prvim redovima ponavlja poražavajuće konstatacije, koje ostaju praktično neizmenjene u odnosu na one iz prvog izveštaja korišćenog u ovom istraživanju, izrađenom pre tačno dve decenije, 1998. godine.

U momentu kada Savet bezbednosti UN donosi odluku o ukidanju mirovne operacije MINUSTAH i uspostavljanju znatno manje follow-up misije, United Nations Mission for Justice Support in Haiti (MINUJUSTH), ${ }^{66}$ uz znatno umanjenje budžeta i aktivnosti specijalizovanih UN agencija i programa, USAID ocenjuje da je stepen deforestacije na Haitiju skoro $98 \%$, što pojačava negativno delovanje tropskih oluja i uragana, inicira naprednu eroziju zemljišta, onemogućava poljoprivrednu proizvodnju i prouzrokuje gomilanje ze-

\footnotetext{
${ }^{59}$ United Nations Response to Cholera in Haiti, http://www.un.org/News/dh/infocus/haiti/factsheet_Haiti_Cholera_Sep2016.pdf

${ }^{60}$ UN, Cholera Response Fact Sheet, August 2016,

http://www.un.org/News/dh/infocus/haiti/CholeraFactsheetAugust2016.pdf

${ }^{61}$ Četvrte kategorije, pri čemu brzine vetra dostižu i do $230 \mathrm{~km} / \mathrm{h}$.

${ }^{62}$ OCHA Hurricane Matthew Situation Report No. 4, 6 Oktobar 2016. godine, http://reliefweb.int/sites/reliefweb.int/files/resources/OCHASituationreport4HurricaneMatthew201610065pmENG.pdf

${ }^{63}$ UNEP, Hurricane Matthew, 10 Oktobar 2016. godine, http://www.unep.org/disastersandconflicts/news/unenvironment-continues-support-people-haiti

${ }^{64}$ OCHA, HAITI: Hurricane Matthew, Situation Report No. 25 (25 Novembar 2016), http://reliefweb.int/report/haiti/haiti-hurricane-matthew-situation-report-no-25-25-november-2016

${ }^{65}$ USAID Haiti, Environment \& Natural Resources Management Fact Sheet, Mart 2017, https://www.usaid.gov/sites/default/files/documents/1862/FINAL_Environment_Fact_Sheet_March_2017.pdf

${ }^{66}$ UNSC Resolution 2350 (2017), http://unscr.com/en/resolutions/doc/2350
} 
mljanih depozita na obalskim i morskim dobrima, dok nekontrolisan lov i ribolov uništavaju već oslabljeni bio-diverzitet ove ostrvske države. Kako USAID dalje navodi, Haiti kao država nije u mogućnosti da se izbori sa izazovima upravljanja otpadnim vodama, a posebno u svom glavnom gradu Port-au-Prince, najvećem gradu u svetu bez kanalizacionog sistema i kontrolisane vodne infrastrukture, tj. teritoriji izuzetno podložnoj širenju zaraznih bolesti sličnih već prisutnoj koleri. Ukratko, degradacija već znatno uništene životne sredine Haitija ostaje ključni egzistencijalni problem i jedna od najozbiljnijih pretnji života celokupne nacije.

Posmatrajući današnju situaciju na Haitiju iz ugla OCHA (UN Office for the Coordination of Humanitarian Affairs), ${ }^{67}$ tj. organizacionog dela sistema UN koja ima za zadatak objedinjavanje aktivnosti humanitarnih činioca u situacijama katastrofalnih razmera, kao što su ona koja su do sada znatno pogađala Haiti - uragani, poplave, zemljotres, sezonske suše, kolera - izveštaj pripremljen početkom 2017. godine na temu Plana humanitarnih aktivnosti (The Humanitarian Response Plan) ${ }^{68}$ na Haitiju u periodu 2017/2018. potvrđuje navode USAID. U izveštaju se opisuje negativan uticaj prirodnih nepogoda i katastrofa na Haitiju kao izniman, imajući u vidu već postojeću socijalno-ekonomsku i ekološku ranjivost, disparitete i uzastopne konvergencije niza humanitarnih kriza, pri čemu populacija, od koje više od polovine živi u ekstremnom siromaštvu, ostaje izuzetno podložna nepovoljnom delovanju prirodih sila. Dešavanja usled poslednjeg takvog primera, uragana Metthew iz oktobra 2016 godine, OCHA navodi kao jasan dokaz da Haiti ne poseduje potrebne defanzivne kapacitete, niti društvenu snagu da se bilo oporavi ili prilagodi uzastopnim šokovima kojima je izložen usled delovanja elementarnih nepogoda.

Uporedo sa najavom Saveta bezbednosti UN o ukidanju mirovne operacije MINUSTAH i značajne reforme formata prisustva međunarodne organizacije u ovoj karipskoj državi, početkom 2017. Haiti dobija novog izabranog predsednika, a Parlament odobrava predloženi kabinet nove vlade u čijem sastavu se nalazi ranije spominjano Ministarstvo za zaštitu životne sredine - za čiji se odobreni Plan rada (Feuille de route / Road map) ${ }^{69}$ opravdano trebalo pretpostavljati da sadrži suverenu procenu stanja eko-sistema životne sredine. Nažalost, uvid u navedenu platformu donosi ne više od seta protokolarnih i administrativnih klauzula, definisanje izazova kao „ogromnih”, te identifikaciju i šturu taksativnu razradu pet osnovnih pravaca delovanja ovog ministarstva, odnoseći se poimenice na: upravljanje prirodnim resursima, sanaciju terena, planiranje teritorije, borbu protiv klimatskih promena, te upravljanje finansijskim resursima. Činjenica ostaje, pored ranije navedene informacije da ovo Ministarstvo raspolaže godišnjim budžetom od skromnih 5,8 miliona USD, da bilo u preambuli ili aneksu platforme jedinog nacionalnog entiteta zaduženog za zaštitu životne sredine ne postoji niti jedna jedina rečenica ili objektivan naučni podatak koji bi definisao njen trenutni status i samim tim, ako ništa drugo, makar pojačao percepciju potrebe ozbiljnog razumevanja problema sa kojim se Haiti suočava u svojoj modernoj istoriji i neumitnoj budućnosti.

\footnotetext{
${ }^{67}$ OCHA, Who We Are, https://www.unocha.org/about-us/who-we-are

${ }^{68}$ The Humanitarian Response Plan ,

https://www.humanitarianresponse.info/system/files/documents/files/haiti_hrp_2017_2018.pdf

${ }^{69}$ Feuille de route du Ministre de l'Environnement, http://www.sgcm.gouv.ht/wp-content/uploads/2017/03/18Feuille-de-route-du-Ministre-de-Environnement.pdf
} 
Pokušaj boljeg uvida u nacionalnu transparentnost po pitanju trenutnog stanja životne sredine na Haitiju putem raspoloživih open source izvora - internet materijala na portalu vlade ove države - rezultira time da link jedino ovog ministarstva od 18 postojećih ne funkcioniše, tj. vodi ka stranici Biroa za rudarstvo i energiju Haitija. ${ }^{70}$ lako je ovo ministarstvo uspostavljeno još 1994. godine radi promocije održivog razvoja i podsticanja na očuvanje životne sredine, ${ }^{71}$ njegov postojeći sajt, ${ }^{72}$ izrađen da bi omogućio najširi mogući outreach i delovanje u smislu racionalnog upravljanja već ozbiljno narušene životne sredine na Haitiju, u kontinuitetu ostaje nefunkcionalan, praktično mrtav, unresponsive.

Može se zaključiti da vlada Haitija, kao principijelan governance organ države Haiti, ne poseduje praktično niti jedan pisani autohtoni izvor informacija koji može uputiti bilo vlastito stanovništvo, bilo njegove legalno izabrane predstavnike (legislative), izvršne organe vlasti (executive), bilo organizaciju UN, MINUSTAH ili pak zainteresovane i kvalifikovane da pomognu elemente šire međunarodne zajednice u self-assessed realno stanje eko-sistema i životne sredine svoje suverene teritorije.

\section{DISKUSIJA: Nalazi komparativne analize ulaganja u razvoj sistema nacionalne i ekološke bezbednosti}

Uporedna analiza ulaganja u razvoj sistema nacionalne i ekološke bezbednosti na Haitiju preduzetih u periodu od 2014/2015. do 2016/2017. godine, respektivno tri finansijske godine, ukazuje ne samo na ekstremne nesrazmernosti, već i na progresivno kvantitativno umanjenje kada govorimo o ukupnim ulaganjima u sistem nacionalne bezbednosti na Haitiju, kako od međunarodnih činilaca, tako i same države, pri čemu ulaganja u sistem životne sredine i ekološke bezbednosti ostaju nepromenjena - apsolutno minimalna.

Ako se umanjenje ukupnih ulaganja u sistem nacionalne bezbednosti može uslovno opravdati činjenicom postepenog povlačenja međunarodne zajednice sa Haitija usled relativne stabilizacije operativnog okruženja (poredeći to sa onim iz 2004. godine, kada je mirovna operacija MINUSTAH prvobitno uspostavljena), nalazi ovog istraživanja ne ukazuju na postojanje pa i minimalnih naznaka za postojanjem razumevanja ili potrebe za većim ulaganjima u domenu zaštite životne sredine i sveukupne ekološke bezbednosti na Haitiju.

Zbirni pregled ukupno uloženih sredstava u oba aspekta bezbednosti, od strane kako međunarodne zajednice tako i Haitija, ukazuje na podatak da je samo skromnih tri procenta od sveukupno uloženih sredstava u posmatranom periodu namenjeno unapređenju ekološke bezbednosti. Naredni grafički prikazi prikazuju statistički model i trend - kao navedeno.

\footnotetext{
${ }^{70}$ http://primature.gouv.ht/?page id=28 -> Ministre de l'Environnement - http://www.bme.gouv.ht/ -> Bureau Des Mines Et De L'énergie D'haïti

${ }^{71}$ Site Web du Ministere de l'Environment d'Haiti, https://unfccc.int/resource/ccsites/haiti/

72 Ibidem.
} 

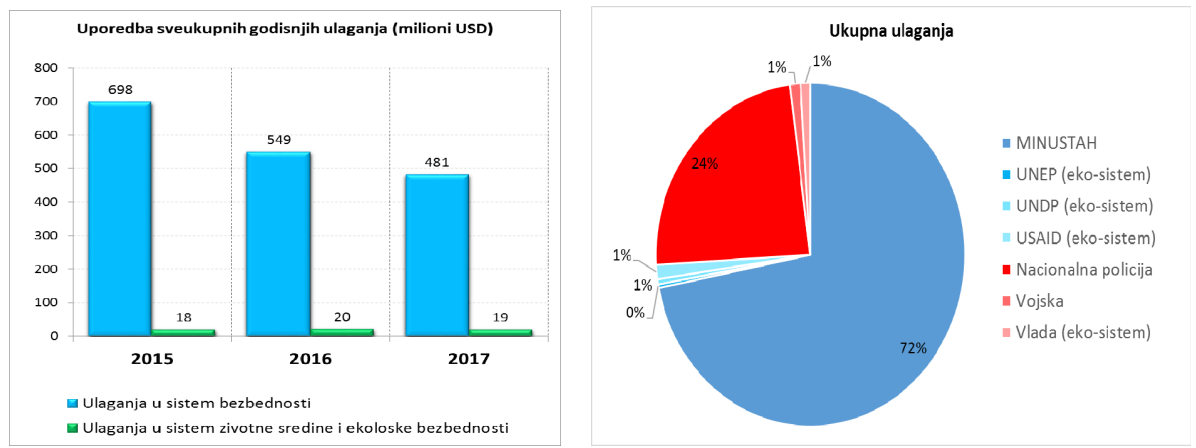

\section{Haiti reality check - jun 2017. godine}

Negativan statistički model i trend predstavljeni u prethodnom odeljku, a kao uvid u stanje realnosti ulaganja u aktuelnom trenutku, bilo posmatran u kontekstu ekološke bezbednosti Haitija u periodu pre uspostave mirovne operacije MINUSTAH, njenog trajanja ili očekivanog ukidanja za samo nekoliko meseci, nameće pitanje o racionalnom savremenom sagledavanju pojma bezbednosnih rizika današnjice, bilo da govorimo o Haitiju, ili nekoj drugoj specifičnoj operativnoj teritoriji (kriznom području) sa izraženim prisustvom i delovanjem međunarodne zajednice i organizacije UN.

lako su opšti bezbednosni uslovi na Haitiju vidno unapređeni od 2004. godine zahvaljujući znatnim ulaganjima u fizički aspekat bezbednosti, država ulazi u period neposrednog gubitka značajne bezbednosne podrške međunarodne zajednice (oktobar 2017), usled nove sezone uragana (traje do 30 . oktobra $^{73}$ - a nakon više od decenije znatnog prisustva i ulaganja međunarodne zajednice i dalje bez kapaciteta ili resursa pri relevantnim institucijama da odgovori na dalju degradaciju životne sredine, eko-sistema i razarajuće delovanje prirodnih katastrofa. Poslednje je naročito vidljivo u južnim delovima zemlje u kojoj je resilience (opšta otpornost) društva izuzetno niska ili praktično nepostojeća nakon prolaska poslednjeg u nizu uragana Matthew, pre nešto manje od godinu dana.

Haiti je već pretrpeo znatne dodatne štete usled teških bujica i izlivanja rečnih korita tokom prve kišne sezone u aprilu i maju 2017. godine,$^{74}$ dok su meteo-analitičari ${ }^{75}$ predvideli, sa 45 procenata verovatnoće, da će Atlantic Hurricane Season 2017 biti iznad normalnog proseka, sa očekivanih 11 do 17 oluja sa brzinama vetra od minimalno $60 \mathrm{~km} / \mathrm{h}$, pet do devet uragana sa brzinama vetra od minimalno $130 \mathrm{~km} / \mathrm{h}$ i dva do četiri major (snažnih) uragana sa brzinama vetra od minimalno $180 \mathrm{~km} / \mathrm{h}^{76}$

\footnotetext{
${ }^{73}$ Seasonal calendar and critical events timeline, http://reliefweb.int/report/haiti/haiti-food-security-updatenovember-2008

${ }^{74}$ Haiti - FLASH: Heavy rain on the South, significant damage (provisional assessment), http://www.haitilibre.com/en/news-20744-haiti-flash-heavy-rain-on-the-south-significant-damage-provisionalassessment.html

${ }^{75}$ National Oceanic and Atmospheric Administration (NOAA) i Colorado State University (CSU).

${ }^{76}$ National Oceanic and Atmospheric Administration (NOAA), http://www.noaa.gov/media-release/abovenormal-atlantic-hurricane-season-is-most-likely-year
} 


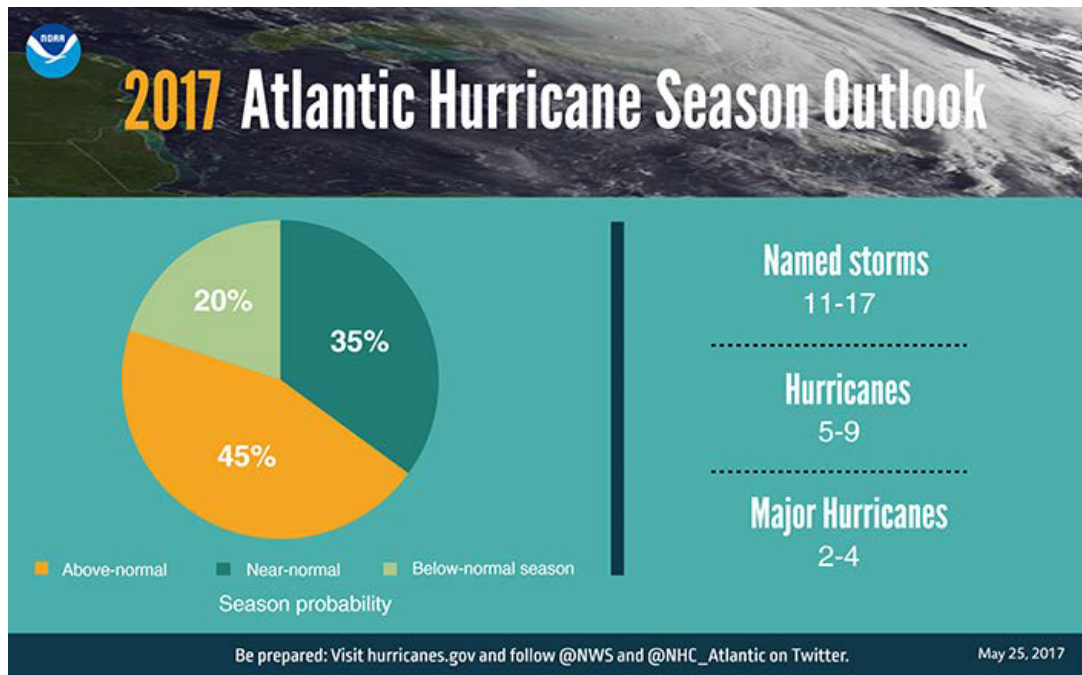

Imajući u vidu da je danas preko $90 \%$ Haićana izuzetno podložno raznovrsnim rizicima negativnog delovanja prirode i okruženja, ova karipska država ostaje sa najizraženijim rejtingom ranjivosti od tropskih ciklona među malim ostrvskim državama Caribbean regiona $^{77}$ - pri čemu je izgledno da će ove godine i Haiti i međunarodna zajednica (UN) opet biti i ostati bezmalo pasivni posmatrači novog negativnog delovanja prirodnih sila u samom vrhu (peak) Hurricane Season 2017, koji se očekuje između 20. avgusta i 15. oktobra. Tim više što se ovaj period upravo poklapa sa prestankom delovanja mirovne operacije MINUSTAH i tranzicije u mirovnu operaciju MINUJUSTH, mnogo manju i manje sposobnu da pruži neophodnu pomoć po pitanju bilo fizičke ili ekološke bezbednosti.

Stoga, može se očekivati da skora budućnost bude svedok negativnih posledica uzrokovanih nesrazmernostima napora uloženih u razvoj sistema nacionalne i ekološke bezbednosti na Haitiju, a posebno zanemarivanja i nepostojanja ulaganja u zaštitu životne sredine, eko-sistem i sistem ekološke bezbednosti - pri čemu proces njihove dalje degradacije predstavlja validnu latentnu negaciju uspeha organizacije UN u stabilizaciji nacionalnog bezbednosnog okruženja koji je trajao više od decenije.

Svi su izgledi da će dalja, više nego izvesna degradacija eko-sistema Haitija, poduprta istorijskim činjenicama, objektivnom trenutnom situacijom i realnim projekcijama, pokazati u kratkom do srednjoročnom periodu backfire efekat na do sada ostvarene relativne uspehe organizacije UN u stabilizaciji nacionalnog bezbednosnog okruženja ove države, što se primarno može očekivati putem novih značajnih pritisaka u širokom domenu socio-ekonomskih odnosa, novih humanitarnih kriza, te opšte bezbednosne, pa konačno i političke situacije.

\footnotetext{
${ }^{77}$ Caribbean Hazard Assessment Mitigation and Preparedness (CHAMP) Initiative, http://www.champ.gatech.edu/
} 


\section{Savremena shvatanja globalnih rizika kao podrška dokazane hipoteze}

Rezultati ovog istraživanja nisu samo u funkciji potvrde uspostavljene hipoteze, već i poražavajući ukoliko se problem sagledava kao predmet menadžmenta kompleksnih kriznih područja, kako od strane međunarodne zajednice (organizacije UN), tako i Haitija.

To se potvrđuje činjenicom da je organizacija UN avgusta 2015. godine, prilikom proglašenja Agende održivog razvoja međunarodne zajednice za period do 2030. godine (Transforming Our World: The 2030 Agenda For Sustainable Development), ${ }^{78}$ predstavljene na 30 strana, jasno stavila do znanja da, pored ostalog, očuvanje, obnova i promovisanje održivih eko-sistema, menadžment šumskih dobara, borba protiv procesa dezertifikacije, sprečavanje degradacije zemljišta i daljeg uništavanja biodiverziteta predstavljaju jedan od ključnih ciljeva sveukupnog održivog društvenog razvoja u budućnosti. To se vidi u oblastima 13 do 15 u priloženoj ikonografiji preuzetoj iz navedenog izveštaja.
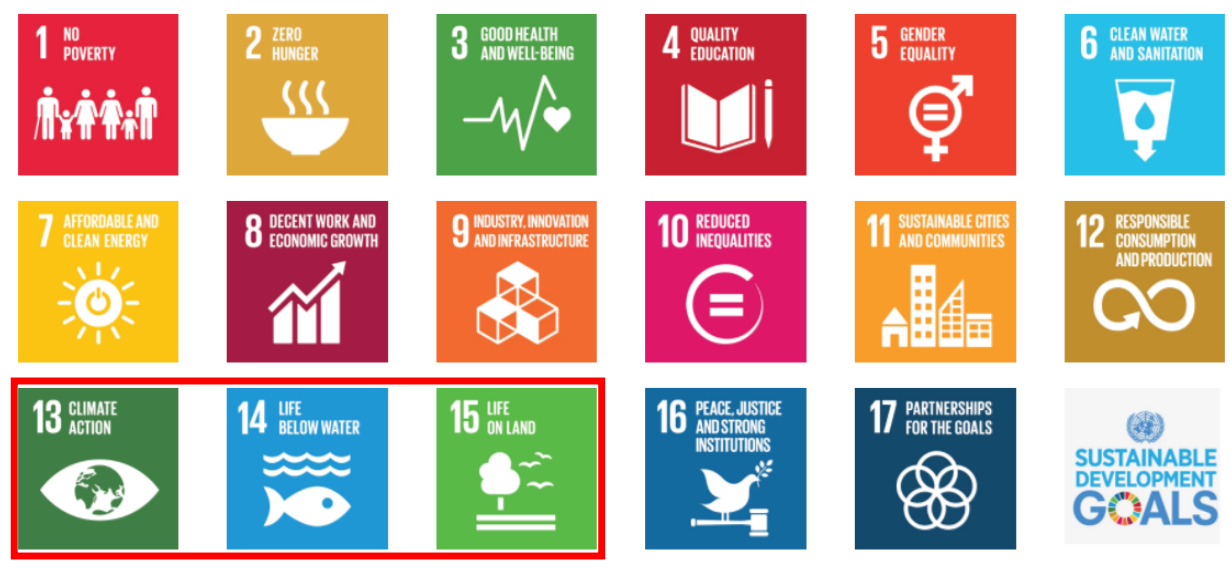

(अ)

SUSTAINABLE DEVELOPMENT

U svakom slučaju, poslednjih deceniju i po ni međunarodna zajednica (organizacija UN), ni vladajućih struktura Haitija nisu ozbiljno razmatrali problem ekološke bezbednosti sa kojima se ova država suočava. Tematika je evidentno tretirana po principu kick the can down the road, uz validnu pretpostavku da se tretiraju po ad-hoch principu, odnosno kada preuzmu vidljivu i dominantu važnost u bezbednosno-političkim agendama višeg reda, a što se obično inicira tek usled scenarija sa velikim stradanjem civilnog stanovništva, uništavanjem javnih dobara, kritične infrastrukture ili industrijskih instalacija.

78 https://www.un.org/pga/wp-content/uploads/sites/3/2015/08/120815_outcome-document-of-Summit-foradoption-of-the-post-2015-development-agenda.pdf 
Kvalitativno pojačanje dokazane hipoteze, te nova potvrda do danas bezmalo neracionalnog pristupa rešavanju pitanja ekološke bezbednosti od strane međunarodne zajednice (organizacije UN) i Haitija u ovoj studiji slučaja dolazi i u formi dodatnog istraživanja najnovijeg datuma, koje je pripremio Svetski ekonomski forum početkom 2017. godine (World Economic Forum - The Global Risks Report 2017). ${ }^{79}$ Ono, upravo poput Agende 2030, postavlja u sam vrh značaja i potencijalnog uticaja globalnih rizika, pored ostalog, grupaciju događaja koji se odnose upravo na životnu sredinu i eko-sistem, a to su: vremenske nepogode (extreme weather events), prirodne katastrofe (major natural disasters), širenje zaraznih bolesti (spread of infectious diseases), neuspeh u mitigaciji ili prilagođavanju promenama klimatskog okruženja (failure of climate-change mitigation and adaptation), te kolaps biodiverziteta i nestanak eko-sistema (biodiversity loss and ecosystem collapse), što je prikazano na priloženoj ikonografiji preuzetoj iz navedenog izveštaja.

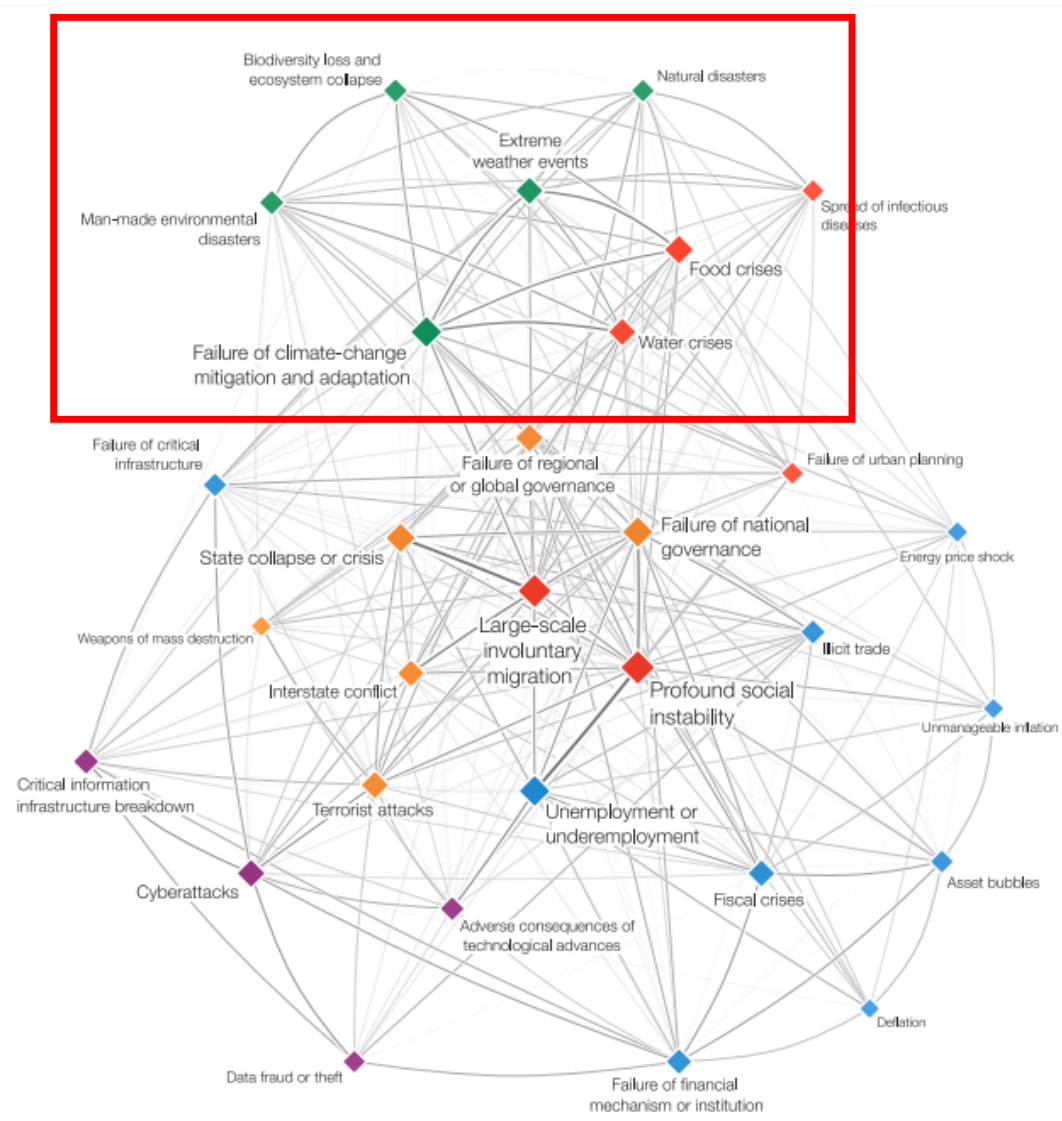

${ }^{79}$ http://www3.weforum.org/docs/GRR17_Report_web.pdf 


\section{Zaključak}

Prikazano istraživanje ekoloških aspekta nacionalnog sistema bezbednosti izvršeno je posmatranjem kroz prizmu delovanja međunarodne zajednice i mirovne operacije organizacije UN na Haitiju, kao višedecenijskom kriznom području. Ukazuje se na nesrazmernost napora uloženih u razvoj sistema nacionalne i ekološke bezbednosti i degradacije eko-sistema Haitija kao latentne negacije relativnog uspeha organizacije UN u stabilizaciji bezbednosnog okruženja ove nacije.

Slučaj Haitija predstavlja klasičan primer direktne uzročno-posledične veze između ekstremno degradiranog eko-sistema i već znatno oslabljenog sistema nacionalne bezbednosti, pri čemu afektirana nacija ne poseduje institucionalne kapacitete da odgovori na nijednu od ovih pretnji ili pak umanji postojeće ekološke rizike. ${ }^{80}$ Naime, zbog nepostojanja validnog nacionalnog sistema upravljanja životnom sredinom dolazi do ubrzanog gubitka bio-diverziteta, osiromašenja zemljišta i erozije njegove kontinuirane erozije usled delovanja tropskih ciklona. ${ }^{81}$

Izuzetna osetljivost eko-sistema Haitija i njegova direktna povezanost sa manjkavostima ili nepostojanjem institucija države i vladavine prava, dugotrajnim socio-ekonomskim krizama, izrazitom bezbednosnom nestabilnošću, te praktičnim haosom u domenu političkog života države, predstavljali su, i još predstavljaju, poznatu kategoriju u okvirima međunarodne zajednice kroz period brojnih postojećih nacionalnih administracija - hronično slabih decenijama.

Haiti se danas nalazi u kritičnoj situaciji usled skoro nastupajućeg drastičnog smanjenja pomoći međunarodne zajednice, dok država ostaje pod značajnim negativnim uticajem identičnih ranije navedenih faktora rizika, uz koje je neophodno navesti i široko raširenu korupciju, transnacionalni kriminal, delovanja ilegalnih oružanih grupa sa kojima se suočava najnovija (februar 2017. godine) neiskusna administracija koja nastavlja praksu deklarativnih političkih poruka po pitanju sprovođenja programa održivog razvoja, te jačanja ili rehabilitacije prirodnih resursa.

Kako je urgentno preusmeravanje trenda degradacije i uništavanja eko-sistema Haitija od kritičnog značaja za njegovu dugotrajnu stabilizaciju i razvoj u svim domenima društvene bezbednosti, kritični događaji u modernoj istoriji Haitija od 2004. godine i odlaganje kvalitativnog pomaka u promeni uspostavljenog negativnog trenda nedvosmisleno predstavljaju tempiranu bombu u formatu neizbežne ekološke katastrofe - kolaps eko-sistema, čije će nerešavanje doprineti evoluciji novih nestabilnosti i ponovnog urušavanja relativno unapređenog sistema šire nacionalne bezbednosti u skoro nastupajućem post-UN periodu.

Realnost nameće da ova problematika i prikazana logika iniciraju nove pristupe, ali i praktične radnje kada se govori o odnosu međunarodne zajednice (organizacije UN) i zemalja primaoca pomoći po pitanju srazmernosti ulaganja u razvoj sistema nacionalne (fizičke) i ekološke bezbednosti.

Posmatrajući organizaciju UN i vlade - administracije država primaoca pomoći, kao nadnacionalne i nacionalne biznis modele najvišeg stepena, može se zaključiti da će biti potrebna znatna ulaganja u resurse, ne samo materijalne, već prvenstveno ljudske, u menadžment prirodnih resursa, ${ }^{82}$ naročito u područjima koja se kreću ka budućnosti u kojoj će ti resursi biti u oskudici, jer se sa sigurnošću može pretpostaviti da će u narastajućem broju failed država doći do većih bezbednosnih potresa.

\footnotetext{
${ }^{80}$ Primera radi, širenje zarazne bolesti kolere bilo je bezmalo nezaustavljivo uprkos nastojanjima Svetske zdravstvene organizacije (World Health Organization) i sistema UN angažovanog na Haitiju.

${ }^{81}$ Dodatni razlozi koji su doveli do nezaustavljive kontaminacije oskudnih izvora pijaće i tehničke vode koji su postali katalizator širenja kolere, odnosno nezapamćenog širenja ove zarazne bolesti u modernoj historiji Haitija.

${ }^{82}$ Top trends impacting business models of today, World Economic Forum, http://reports.weforum.org/futureof-jobs-2016/basic-infrastructure/
} 


\section{Konsultovani otvoreni izvori}

[1] Adaptation basée sur les écosystèmes, http://www.ht.undp.org/content/hait//fr/home/operations/projects/environment_and_energy/adaptati on-basee-sur-les-ecosystemes.html

[2] Appui au Renforcement des Capacités du Ministère de l'Environnement, http://www.ht.undp.org/content/hait//fr/home/operations/projects/environment_and_energy/renforce ment-des-capacites-adaptatives-des-communautes-cotieres-.html

[3] Budget général de la République 2014-2015, http://www.mef.gouv.ht/upload/doc/Budget_Rectificatif_14-15.pdf

[4] Budget général de la République 2015-2016, http://dgi.gouv.ht/wp-content/uploads/2016/03/Budget_initial_2015-2016.pdf

[5] Budget général de la République 2016-2017, http://www.mef.gouv.ht/upload/doc/Budget-2016-2017.pdf

[6] Currency Exchange, http://www.xe.com/currencycharts/?from=USD\&to=HTG\&view=5Y

[7] Développement de l'hydroélectricité sur petite échelle en Haïti, http://www.ht.undp.org/content/haiti/fr/home/operations/projects/environment_and_energy/projethydroelectricite.html

[8] Dollars to Results, Environment in Haiti, https://results.usaid.gov/haiti/environment\#fy2015

[9] Environmental Scarcities And Conflict in Haiti, Ecology and Grievances in Haiti's Troubled Past and Uncertain Future, Philip Howard, For the Canadian International Development Agency, June 1998, Contract No. 26248, http://www.gvsu.edu/cms3/assets/53940C9B-B252-5B69626B48622A4C1002/publishedliterature/haitienvironmental_scaricity.pdf

[10] Feuille de route du Ministre de l'Environnement, http://www.sgcm.gouv.ht/wpcontent/uploads/2017/03/18-Feuille-de-route-du-Ministre-de-Environnement.pdf

[11] Final Report of the Independent Panel of Experts on the Cholera Outbreak in Haiti, http://www.un.org/News/dh/infocus/haiti/UN-cholera-report-final.pdf

[12] Financing of the United Nations Stabilization Mission in Haiti, http://www.un.org/ga/search/view_doc.asp?symbol=A/RES/68/289

[13] Financing of the United Nations Stabilization Mission in Haiti, http://www.un.org/ga/search/view_doc.asp?symbol=A/RES/69/299

[14] Haïti - Politique: 5 nouvelles communes en Haïti, http://www.haitilibre.com/article-14858-haiti-politique-5-nouvelles-communes-en-haiti.html

[15] Haiti, Human Development Indicator, http://hdr.undp.org/en/countries/profiles/HTI

[16] Haiti: Saving the Environment, Preventing Instability and Conflict, Policy Briefing, International Crisis Group, Latin America and Caribbean Briefing N²0, Port-au-Prince/Brussels, 28 April 2009, https://www.crisisgroup.org/latin-america-caribbean/hait//haiti-saving-environmentpreventing-instability-and-conflict

[17] Haiti's Multi-Billion Dollar Humanitarian Aid Problem, http://www.huffingtonpost.com/young-professionals-in-foreign-policy/haitis-multi-billion-doll_b_8207494.html

[18] Haitian Government Reinstates the Army, http://www.globalresearch.ca/haitian-government-reinstates-the-army/5494680

[19] Klimatski kalendar i kalendar dešavanja: http://www.fews.net/file/87819 , https://en.wikipedia.org/wiki/2004_Atlantic_hurricane_season

[20] Le Ministère de l'Economie et des Finances, http://www.mef.gouv.ht/

[21] Ministère de l'Environnement d'Haiti, https://unfccc.int/resource/ccsites/haiti/ 
[22] Ministere de l'Environnement, https://unfccc.int/resource/ccsites/haiti/

[23] Ministere de la Defense, http://www.md.gouv.ht/

[24] MINUSTAH Background,

http://www.un.org/en/peacekeeping/missions/minustah/background.shtml

[25] MINUSTAH Budget Database,

http://www.un.org/ga/acabq/documents/all?type $\% 5 B \% 5 \mathrm{D}=$ report\&type $\% 5 \mathrm{~B} \% 5 \mathrm{D}=$ document\&year $\% 5$ Bvalue $\% 5$ D\%5B\%5D=2011\&keys=MINUSTAH

[26] MINUSTAH Budget, 1 July 2005 to 30 June 2006 and expenditure report, 1 May to 30 June 2004, http://www.un.org/ga/search/view_doc.asp?symbol=A/59/745

[27] MINUSTAH Financing, http://www.un.org/ga/search/view_doc.asp?symbol=A/RES/65/256B

[28] OCHA Hurricane Matthew Situation Report No. 4,

http://reliefweb.int/sites/reliefweb.int/files/resources/OCHASituationreport4HurricaneMatthew20161 0065pmENG.pdf

[29] OCHA, HAITI: Hurricane Matthew, Situation Report No. 25,

http://reliefweb.int/report/haiti/haiti-hurricane-matthew-situation-report-no-25-25-november-2016

[30] OCHA, Who We Are, https://www.unocha.org/about-us/who-we-are

[31] Office of the UN SG Special Adviser, Aid to Haiti after the January 12, 2010 earthquake, http://www.lessonsfromhaiti.org/lessons-from-haiti/key-statistics/

[32] PAHO-WHO, Epidemiological Update, Cholera in the Americas - Situation summary, http://reliefweb.int/sites/reliefweb.int/files/resources/2017-feb-23-phe-epi-update-cholera.pdf

[33] Police Nationale d'Haiti, http://www.pnh.ht/

[34] Programme de Micro Financement,

http://www.ht.undp.org/content/hait//fr/home/operations/projects/environment_and_energy/program me-de-micro-financement.html

[35] Projekti UNDP na Haitiju,

http://www.ht.undp.org/content/haiti/fr/home/operations/projects/overview.html

[36] Projekti usmereni na podršku i razvoj Eko-sistema i zaštitu životne sredine UNDP na Haitjju, http://www.ht.undp.org/content/haiti/fr/home/operations/projects/environment_and_energy.html

[37] Renforcement des capacités adaptatives des communautés côtières d'Haïti aux changement climatique,

http://www.ht.undp.org/content/haiti/fr/home/operations/projects/environment_and_energy/renforce ment-des-capacites-adaptatives-des-communautes-cotieres-.html

[38] Report of the Secretary-General on the United Nations Stabilization Mission in Haiti, http://www.undocs.org/S/2017/223

[39] Report of the Secretary-General on the United Nations Stabilization Mission in Haiti, https://minustah.unmissions.org/sites/default/files/s2016753_en.pdf

[40] Report of the Secretary-General on the United Nations Stabilization Mission in Haiti, 22 February 2010, http://www.securitycouncilreport.org/att/cf/\%7B65BFCF9B-6D27-4E9C-8CD3CF6E4FF96FF9\%7D/Haiti\%20S2010\%20200.pdf

[41] Security Council Establishes UN Stabilization Mission in Haiti for Initial Six-Month Period, http://www.un.org/press/en/2004/sc8083.doc.htm

[42] Security Council Grants Final Mandate Extension for MINUSTAH, Unanimously Adopting Resolution 2350 (2017), https://www.un.org/press/en/2017/sc12794.doc.htm

[43] Site Web du Ministere de l'Environment d'Haiti, https://unfccc.int/resource/ccsites/haiti/ 
[44] The Guardian, Paris climate change agreement: the world's greatest diplomatic success, https://www.theguardian.com/environment/2015/dec/13/paris-climate-deal-cop-diplomacydeveloping-united-nations

[45] The Haiti 'Grand Sud' Programme, http://drustage.unep.org/disastersandconflicts/wherewe-work/haiti/what-we-do/haiti-\%E2\%80\%98grand-sud\%E2\%80\%99-programme

[46] The Humanitarian Response Plan , https://www.humanitarianresponse.info/system/files/documents/files/haiti_hrp_2017_2018.pdf

[47] The UN System: http://cifal-flanders.org/united-nations/un-system/

[48] UN Environment Project Presence, http://uneplive.unep.org/redesign/theme/index/11\#maps

[49] UN Regular Budget and Environment Fund, http://www.unep.org/about/funding/our-funding/overview

[50] UN Response to Cholera in Haiti, http://www.un.org/News/dh/infocus/haiti/factsheet_Haiti_Cholera_Sep2016.pdf

[51] UN, Cholera Response Fact Sheet, August 2016, http://www.un.org/News/dh/infocus/haiti/CholeraFactsheetAugust2016.pdf

[52] UN, Climate Change Conference Paris 2015, http://www.un.org/sustainabledevelopment/cop21/

[53] UN, Paris Agreement Signing Ceremony, 22 April 2016, http://www.un.org/sustainabledevelopment/parisagreement22april/

[54] UN, Sustainable development goals 2030, Sustainable development, http://www.un.org/sustainabledevelopment/sustainable-development-goals/

[55] UN, The Paris Agreement, http://unfccc.int/paris_agreement/items/9485.php

[56] UN, Transforming Our World: The 2030 Agenda for Sustainable Development, https://sustainabledevelopment.un.org/content/documents/21252030\%20Agenda $\% 20$ for $\% 20$ Sustai nable\%20Development\%20web.pdf

[57] UN's Ban apologizes to people of Haiti, outlines new plan to fight cholera epidemic and help communities , http://www.un.org/apps/news/story.asp?NewsID=55694\#.WQfmDRMrldU

[58] UNDP Haiti, Protection de l'environnment, http://www.ht.undp.org/content/haiti/fr/home/operations/projects/environment_and_energy.html

[59] UNDP, About Us, http://www.undp.org/content/undp/en/home/operations/about_us.html

[60] UNDP, http://www.undp.org/content/undp/en/home.html

[61] UNEP, http://web.unep.org/

[62] UNEP, Hurricane Matthew, http://www.unep.org/disastersandconflicts/news/un-environment-continues-support-people-haiti

[63] USAID Haiti, Environment \& Natural Resources Management Fact Sheet, https://www.usaid.gov/sites/default/files/documents/1862/FINAL_Environment_Fact_Sheet_March_2017.pdf

[64] USAID Haiti, Environment \& Natural Resources Management Fact Sheet, Mart 2017, https://www.usaid.gov/sites/default/files/documents/1862/FINAL_Environment_Fact_Sheet_March_2017.pdf

[65] USAID Projects in Haiti Database, https://results.usaid.gov/data

[66] USAID, https://www.usaid.gov/

[67] USAID, Where We Work, https://www.usaid.gov/where-we-work

[68] World Economic Forum - The Global Risks Report 2017, http://www3.weforum.org/docs/GRR17_Report_web.pdf 